\title{
Article
}

\section{'A pest to society': the Charity Organisation Society's domiciliary assessments into the circumstances of poor families and children}

Skinner, Anne and Thomas, Nigel

Available at http://clok.uclan.ac.uk/19601/

Skinner, Anne and Thomas, Nigel ORCID: 0000-0002-5310-9144 (2017) 'A pest to society': the Charity Organisation Society's domiciliary assessments into the circumstances of poor families and children. Children \& Society . ISSN 0951-0605

It is advisable to refer to the publisher's version if you intend to cite from the work. http://dx.doi.org/10.1111/chso.12237

For more information about UCLan's research in this area go to http://www.uclan.ac.uk/researchgroups/ and search for <name of research Group>.

For information about Research generally at UCLan please go to http://www.uclan.ac.uk/research/

All outputs in CLoK are protected by Intellectual Property Rights law, including Copyright law. Copyright, IPR and Moral Rights for the works on this site are retained by the individual authors and/or other copyright owners. Terms and conditions for use of this material are defined in the policies page. 


\title{
'A pest to society': the Charity Organisation Society's domiciliary assessments into the circumstances of poor families and children
}

\author{
Annie Skinner* and Nigel Thomas $\dagger$ \\ *School of History, Philosophy and Culture, Oxford Brookes University, Oxford, \\ $\mathbf{U K}^{1}$ \\ $\uparrow$ School of Social Work, Care and Community, University of Central \\ Lancashire, Preston, UK
}

\begin{abstract}
This article examines the work of the Charity Organisation Society (COS) in assessing applications for children's admission to care in the late nineteenth-century. It is based on an archive study of records kept by the 'Waifs and Strays' Society in England and Wales between 1882 and 1899, in particular 270 family assessments conducted by the COS. The focus was on parental behaviour rather than children's needs, with a strong narrative of taking children away to relieve parents of a burden. The research illuminates contested assumptions about childhood in the period, with resonance for current issues in policy and practice.
\end{abstract}

\section{Introduction}

During the latter decades of the nineteenth-century, poor families faced with crises due to poverty, ill-health or misfortune were dependent on a combination of State and voluntary agencies for help. Three major voluntary organisations were established to provide residential child care services during this time, as an alternative to the workhouse: Dr Stephenson's Homes, founded in 1868 by Thomas Stephenson a Methodist minister; Dr Barnardo's Homes, founded in 1870 by Thomas Barnardo; and the Church of England Incorporated Society for Providing Homes for Waifs and Strays, founded in 1881 by Edward Rudolf. All three still operate as, respectively, Action for Children, Barnardo's and The Children's Society (Parker, 1990; Philpot, 1994; Soares, 2014; Wagner, 1979; Ward, 1990). The London Society for the Protection of Cruelty to Children, which became the NSPCC, was established around the same time (Behlmer, 1982). State provision for children was administered under the Poor Law, and if necessary children would be admitted to a workhouse (Crompton, 1997).

Attitudes towards childhood and child welfare were shifting at the time, prompted by the work of reformers such as Florence Davenport and Mary Carpenter (Cunningham,

\footnotetext{
1 Correspondence to: Dr Annie Skinner, School of History, Philosophy and Culture, Oxford Brookes University, Gipsy Lane, Oxford OX3 0BP, UK, Tel.: +01865 246585. E-mail: askinner@ brookes.ac.uk.
} 
1991; Hendrick, 1997; Heywood, 1978; Pinchbeck and Hewitt, 1983). At the same time, fears from the middle and upper classes that their comfortable moral and economic standards would be threatened by the 'residuum' were becoming more intense in the late 1860s and 1870s (Stedman Jones, 1971). Contemporary surveys and commentators highlighted the extent of poverty in the nineteenth-century (Booth, 1889; Mayhew, 1885; Mearns, 1883; Rowntree, 1901). Nevertheless the Government continued a purge on public spending from 1869. The 'crusade' against outdoor relief generated by the Goschen minute restricted the provision of material support at home. ${ }^{1}$ Goschen, President of the Poor Law Board and a member of the Cabinet in this capacity, advised Guardians to offer relief in the workhouse only. His other advice to Guardians was to distinguish between the 'reputable' and 'disreputable' poor. Clear boundaries relating to responsibilities between Poor Law and voluntary action were established, aiming to reduce state help and promote voluntarism (Harris, 1994; Hollen Lees, 1998; Hurren, 2007; Kidd, 1999; Lewis, 1995; McKinnon, 1987; Rose, 1986; Thane, 2012).

The Charity Organisation Society (COS), established in 1869, shared the harsh philosophy of the New Poor Law. ${ }^{2}$ The COS worked with the Poor Law authorities and developed a system of personal social work to change an individual's behaviour, enabling them to become self-sufficient (Lewis, 1991; Mowat, 1961, Rooff, 1972, Smith, 1965, Webb, 2007, Whelan, 2001, Woodroofe, 1962, Young and Ashton, 1956). The importance of COS in the development of the social work profession is undeniable (although there were other influences; Burnham, 2010). Absent from the history of child care and social work is how professionals managed crises in families in the community. This paper makes a contribution in this area by presenting a case study of the COS's domiciliary assessments of applications for admission to the Waifs and Strays Society (WSS) in the late nineteenth century. Through analysis of these assessments, insights are gained into professional attitudes towards poor families where parents were struggling to provide for their children.

\section{The COS and its role in family assessment}

The COS supported government welfare policy in the latter decades of the nineteenthcentury (Lewis, 1995). Goschen planned for cooperation between the Poor Law Board and the COS with its influential members (Humphreys, 1995). Although Goschen acknowledged that poverty could be the result of unavoidable circumstances rather than a life-style choice (Harris, 1994), the interpretation of 'deserving' and 'undeserving' was subjective. Before poor people could access welfare they had to access mutual aid, which was not easy for those not in regular work, particularly women (Thane, 2012). COS members were encouraged to stand as Poor Law Guardians and join other organisations that helped the poor, providing opportunities to influence them with their policies (Mowat, 1961; Skinner, 2015). 
In pursuit of its objectives of reducing out-door relief, centralising charitable resources, separating the deserving from the undeserving and encouraging self-help, the COS introduced 'scientific' methods to assess applicants (Webb, 2007). This was combined with the 'casework' approach, whereby visitors would work in the applicant's home to educate them to become responsible and thrifty (Lewis, 1995; Mowat, 1961; Prochaska, 1980; Whelan, 2001; Woodroofe, 1962). The principal focus was not on child welfare, but rather on changing adult behaviour (Dingwall et al. 1984; Maxwell, 1997). Visitors were advised that poor families would not benefit immediately from COS help, because it was necessary to investigate the causes of poverty rather than focus on the effects (Humphreys, 1995). Scrutiny was essential in the investigative process, as was made clear in the Fifth Annual Report: 'Careful investigation of applications for charitable aid, by competent officers, each case being duly considered, after inquiry, by a Committee of experienced volunteers...' (Charity Organisation Society 1875: 5-6). The 'scientific' methods incorporated systematic case-notes in an attempt to secularise and systemise the practice of visiting, making a 'scientific' instrument of charity (Himmelfarb, 1991). However, the COS was willing to work with an agency supported by the established Church in order to help counter the threat of the underclass (Stedman Jones, 1971).

Within the WSS the COS were part of the infrastructure from the start. Application forms to the WSS on behalf of a child were verified by the parish cleric. A Case Committee, including COS members, met fortnightly to review and validate applications. The COS were requested to investigate whether the applications were deserving or undeserving according to the eligibility criteria (Our Waifs and Strays, January 1884). Rudolf prioritised this from the outset (Rudolf, 1922), in order to ensure that the WSS was not taking over parental responsibilities unnecessarily (Our Waifs and Strays, January 1884). The COS also referred families to the WSS of their own volition. Payment for child care had to be guaranteed by a sponsor, parent or relative, although some free places were available.

COS help would usually be requested at a local office. A visitor would make a home visit, compile a detailed report of the circumstances, make further enquiries on the applicant then submit the information to a district or sub-committee where a decision whether to give help would be made (Mowat, 1961). The visitors were usually middleclass women (Prochaska, 1980); however, there was a mix of people visiting applicants to the WSS including agents and visitors, male and female. Leading members of the COS made assessments, including Charles Loch, Helen Bosanquet, and Alice Lee. ${ }^{3}$

\section{Research methods and cases examined}

In order to identify the involvement of the COS, all available successful applications to the Waifs and Strays Society (WSS) from 1882 to 1899 were read. During this time there were 7400 successful applications; because some files were being conserved and 
others were not accessible, only 6824 cases have been documented.. A dataset was constructed in SPSS using family details on the application forms: geographical location, age and gender. Reasons for care were categorised as shown in Table 1. Additional information was collected for applications with COS involvement which were analysed to identify themes and patterns. WSS documentary sources were consulted to contextualise policies and procedure against practice.

In total, children were admitted from 267 locations in 60 counties, with more referrals from urban than rural areas. Among the total of 6824 cases, 270 were identified as having COS involvement, from 18 counties across England and Wales. Again, most were from urban areas. It was not always evident on the application form if the referrer was a COS member. Some COS members were only identified because reports in the child's file were from the COS. Given these incidents it is probable that there were more COS referrals than those documented. However, this sample provides an important insight into the COS practice in child care.

Table 1 shows that the referrals involving the COS in general followed the overall pattern of cases admitted by the WSS, but with a greater preponderance of financial problems and parental illness. Table 2 shows that the majority of children admitted were aged 6-10 (60.8 per cent), with substantially more boys than girls.

Table 1: Reasons for Care for WSS and COS applicants

\begin{tabular}{l|llll} 
& COS cases & \% & All cases & $\%$ \\
\hline Parent Ill & 27 & 10.0 & 386 & 5.7 \\
Parent Died & 56 & 20.7 & 1340 & 19.6 \\
Moral Danger & 19 & 7.0 & 633 & 9.3 \\
Abuse & 2 & 0.7 & 192 & 2.8 \\
Neglect & 27 & 10.0 & 973 & 14.3 \\
Child's Behaviour & 6 & 2.2 & 372 & 5.5 \\
Destitute & 5 & 1.9 & 381 & 5.6 \\
Parent's Mental Health & 6 & 2.2 & 76 & 1.1 \\
Financial & 103 & 38.1 & 952 & 14.0 \\
Child's Health Needs & 5 & 1.9 & 134 & 2.0 \\
Other & 6 & 2.2 & 1088 & 15.9 \\
Not Known & 8 & 3.0 & 297 & 4.4 \\
Total & $\mathbf{2 7 0}$ & $\mathbf{1 0 0}$ & $\mathbf{6 8 2 4}$ & $\mathbf{1 0 0}$ \\
& Source: WSS archives & &
\end{tabular}


Table 2: COS Cases by Age and Gender

\begin{tabular}{|c|c|c|c|c|}
\hline Age & Female & Male & Total & $\%$ \\
\hline$<1$ & 1 & 0 & 1 & 0.4 \\
\hline 1.0 & 1 & 0 & 1 & 0.4 \\
\hline 2.0 & 1 & 2 & 3 & 1.1 \\
\hline 3.0 & 3 & 3 & 6 & 2.2 \\
\hline 4.0 & 7 & 12 & 19 & 7.1 \\
\hline 5.0 & 7 & 18 & 25 & 9.3 \\
\hline 6.0 & 9 & 19 & 28 & 10.4 \\
\hline 7.0 & 12 & 26 & 38 & 14.2 \\
\hline 8.0 & 12 & 25 & 37 & 13.8 \\
\hline 9.0 & 15 & 18 & 33 & 12.3 \\
\hline 10.0 & 14 & 14 & 28 & 10.4 \\
\hline 11.0 & 7 & 6 & 13 & 4.9 \\
\hline 12.0 & 12 & 5 & 17 & 6.3 \\
\hline 13.0 & 7 & 1 & 8 & 3.0 \\
\hline 14.0 & 6 & 0 & 6 & 2.2 \\
\hline 15.0 & 3 & 0 & 3 & 1.1 \\
\hline 17.0 & 1 & 0 & 1 & 0.4 \\
\hline 21.0 & 1 & 0 & 1 & 0.4 \\
\hline Total & 119 & 149 & 268 & 100.0 \\
\hline
\end{tabular}

Nearly all (96\%) of the COS cases had family members living and recorded on their assessment forms; 239 (88.5 per cent) had siblings; 191 children (70.7 per cent) had mothers living; 48 children (17.8 per cent) had fathers present; 173 (64.1 per cent) had fathers who had died. The typical child admitted was therefore aged between 6 and 10 years, with a lone mother and siblings.

In the following sections we present the findings under the main themes identified in examining the cases studied: responses to illegitimacy and desertion; responses to 
illness and bereavement; 'casework' and social control; and inconsistencies in the COS approach to cases.

\section{Illegitimacy and desertion}

Illegitimacy was regarded as a moral failure by the authorities, and outdoor relief was not normally provided for illegitimate children under the Poor Law (Cody, 2000; Frost, 2013; Ward, 1990). Regarding WSS admission policy for illegitimate children, instructions were given to referrers in the Society's Handbookfor Workers. If there was more than one illegitimate child in the family the WSS would not usually accept the child, to ensure that the WSS was not colluding with immoral behaviour. Loch's comments on the following application form revealed COS attitudes towards illegitimacy and desertion:

Mary R (4), abandoned by her mother, was left in the care of two widowed aunts. Her mother's payments ceased after six months. Loch advised of the COS decision: 'It is not want of sympathy that leads them to this judgement but they think it is essential that charity, since a choice must be made, should confine its benefits to cases for which the Poor Law does not provide.' (WSS345:1884).

On the face of it Loch's argument here is logical, in that alternatives were available for those who come under Poor Law jurisdiction. However, in practice this meant consigning a little girl to the workhouse when she could have been supported in her family or cared for by the WSS. Even in the context of the COS aim of changing adult behaviour this is not logical, since the widowed aunts were not responsible for the little girl's conception, nor was the child herself; indeed, in the spirit of the COS philosophy the aunts should rather have been commended for responsible behaviour.

There were other cases of illegitimate children being refused help by the COS, such as that of Mrs H, a widowed mother to William (7) (WSS219:1883). Loch's reason for refusal was that since her husband's death Mrs $\mathrm{H}$ had borne an illegitimate child, which he declared was irresponsible as she was unable to maintain herself. An undercurrent of disapproval of Mrs H's sexual behaviour was implicit in this judgement. Whilst this attitude is moralistic and gendered, it is perhaps more in keeping with COS philosophy. Loch was not always consistent in his approach to illegitimacy; in the case of Richard (8) he advised that being illegitimate should not preclude the child being placed in WSS accommodation (WSS34:1882). The circumstances of this case were not remarkable, except that Richard's mother was described as a 'superior woman'. This inconsistency suggests that moral judgements of more than one kind were operative in COS decisionmaking (Livesey, 2004).

As a senior employee of the COS, Loch's contributions to the WSS applications mark those cases as particularly significant, since his comments and decisions set the tone for the work of other COS assessors. His contributions were more frequent in the early 
years of the WSS, suggesting that the COS wanted to assert their authority in line with their priorities. The COS' main objective was to change adult behaviour, whereas the WSS' priority was to rescue children from hardship. Conflict arose between the two organisations in relation to illegitimate children, where the COS wanted children to be consigned to the Poor Law but Rudolf rejected this advice and kept the children. Ward (1990) considers that the WSS were, by the standards of the time, lenient towards illegitimacy. However, there was also inconsistency in the Guardians' responses towards supporting illegitimate children under Poor Law care (Frost, 2013).

Deserted mothers were also seen to be the responsibility of the Poor Law. The Guardians could prosecute husbands for maintenance. If a deserting father maintained his child this would relieve the state's financial responsibilities. The mother of William (6) and Annie (4), was advised by magistrates to 'enter the workhouse' so that the Guardians could instigate procedures to locate and prosecute their father. After four days in the workhouse the mother discharged herself and her children because of the 'behaviour and language of the inmates'. Her local COS committee agreed that the workhouse was not 'a fit place for a respectable woman'. Although the magistrates' recommendation was considered harsh, the COS Committee conceded that as 'the case is one of exceptional difficulty' the decision was seen to be appropriate (WSS354/5:1884). COS enquiries determined her to be respectable and able to live independently on a 'modest wage' if her children were accommodated. Despite her husband deserting her and having to enter a workhouse this mother was seen as respectable. Although she was admitted under the Poor Law to the workhouse this course of action was seen to be inappropriate for her by the COS because she was respectable with good intentions and prospects of finding employment. This was not always the attitude for deserted wives. In the case of a 9 year old girl whose father deserted the family and whose mother had died, leaving no relatives to support her, Loch advised that there were 'no special features which render it desirable to remove it from the action of the Poor Law' (WSS247:1883). This decision reflects COS attitudes to parental antecedents, rendering a vulnerable little girl responsible for her father's actions.

Deserting fathers were seen as having 'bad character'; but there was also suspicion amongst the COS that applicants were not always telling the truth. Mrs B, the mother of Edward (7) and Joseph (6), had remarried after her first husband died. She applied to the COS for help, claiming that her new husband had deserted her. Investigations by the COS raised concerns about the truthfulness and reliability of her story. COS enquiries discovered that her husband was in hospital and that she had visited him there. As their mother worked, the boys were cared for by a woman whom the COS considered 'a most objectionable character', who was allegedly cohabiting, and there were concerns about the influence on the children: ' ...there is no doubt, that if the children are not placed in some such valuable institution as yours, they will grow up to be a pest to society, instead of useful men' (WSS207/208:1883). Because their mother 
worked and needed childcare Edward and Joseph had been placed in inappropriate care, which was common for the time. The boys were neglected, and in the view of the COS the carer was a bad influence on them and they were in danger of becoming uncontrollable. The additional need in this case was to remove the brothers from both the mother and the carer.

Lifestyles of deserted wives were also under scrutiny to ascertain whether they were 'irresponsible' or 'immoral' (Levine-Clark, 2010). Any indication of possible immorality would result in the COS suspending help. Children were effectively punished for their parents' behaviour as their placements were in jeopardy. This was in contrast to health problems, where initial responses from the COS were usually more sympathetic.

\section{Illness and bereavement}

Death or illness of a parent could plunge a family into unexpected poverty. Implicit criticism was often levelled at the breadwinner for being improvident and not preparing for this eventuality. A priority for the COS was to ensure that the remaining parent found employment as soon as possible so that she, or he, would not be dependent on state benefits or charity. In order for the parent to be able to take up employment their children would be received into care. Sometimes just one child would be accommodated by the WSS, as this was considered sufficient to enable the parent to continue working and manage the remaining children. Assessments were carried out very soon after a bereavement, in some cases just days after a spouse had died. The following case is representative of similar situations dealt with by the COS.

Ten months after Mrs R's husband died of consumption, she asked for help. Mrs $R$ had six children, including a 13 year old daughter who was caring for younger siblings whilst her mother was at work. Relying on older children for care of their younger siblings was a common solution for parents, but not always appropriate as the dynamics between the siblings caused problems, the older child missed out on schooling and was often exploited (Davin, 1996). Edward (5) was reported to be 'out of control' and might get into mischief while his mother was at work (WSS200:1883).

Edward was therefore separated from his family despite his age. It is possible that his behaviour was a reaction to his father's death.

Combinations of care were organised on occasions, with the COS pressurising relatives (who might be already struggling to help out). Mothers were making decisions about separation from their children at a crucial time of bereavement. Little empathy was reflected in the case-files from the COS visitor regarding the mother and child relationship. On the contrary, the children were often described as a 'burden', as in comments such as: '...necessary Mrs M should be freed from the care of her two elder 
children at once.' (WSS5401:1897) '...but if relieved of part of her burden...' (WSS101:1882) '...especially if rid of the boy...' (WSS5403:1897).

The justification for removing the children was that the parent was thereby enabled to be self-sufficient. Middle-class values of philanthropists, in line with the underpinning political objectives of their organisation, dominated the casework management of the family. Apart from an occasional request for the child to be placed near their family for visiting access, no regard was given to the impact of separating children from their families.

\section{'Casework' and social control}

The COS made detailed inquiries in a way that was considered to be scientific and progressive, quizzing landlords past and present, neighbours, relatives, employers and professionals to establish whether parents were of 'good character'. Expressed in the assessments were views ranging from character appraisal to speculation on life-styles, standards of housework and material possessions, childcare abilities, antecedents, prognosis of illness, intellectual abilities, employment possibilities, behaviour problems, material possessions, neighbourhood environment, class and a view on the case. Financial assessments were carried out, as were enquiries into arrangements from family members. The COS could be forceful and insistent, as demonstrated in the following examples:

When the mother of two brothers (11) and (10) was in an asylum and their father, $a$ 'dwarf' unable to get regular work, requested admission, the COS were initially supportive: 'The only trade he can do is cigar making, and he is so slow at that, that he earns very low wages and can't support both boys. As he is much handicapped by his infirmity, but is of excellent character, we feel that he ought not to be left to half starve himself and the children and the best way of helping him would be to take one of the boys off his hands.' Later, however, this COS help ended because the father was 'not cooperating' and had not become self-supporting. Despite the previous assessment acknowledging that the father was disabled and therefore unable to obtain well-paid work, assistance was withdrawn (WSS4394 \& WSS6496:1895).

Orphans Wilhelmina (11) and her younger brother lived in one room with their 62 year old grandmother who was struggling to work and provide for them. Wilhelmina was considered 'ignorant and untrained' as she cared for her younger brother while her grandmother was working. The COS and the Relieving Officer both declined to help the grandmother unless she parted with the children, which she persistently refused to do until a fortnight before the referral. On the strength of this permission the COS awarded the grandmother a grant while she was ill. However, the COS and Relieving Officer deemed her unfit for hard work and incapable of keeping herself and the children. The COS had power to force her to 
have the children admitted to the WSS by refusing to give any help unless she did (WSS747:1886).

Approximately six weeks after her father died, Elizabeth's mother was persuaded to have Elizabeth (9), one of six children, admitted to care. Two months later Mrs $S$ withdrew the application because she did not want to lose her daughter. The COS letter to the WSS expressed concern about Mrs S's change of mind: '...in a moment of inconsiderate maternal feeling she has written to you declining the offer of a home for Elizabeth on the grounds she cannot give her up to the age of 17.' Following a COS visit Mrs S apologised for her inconstancy, and Elizabeth was admitted. A year later the COS advised WSS that they could not help any longer, because Mrs $S$ refused to let Elizabeth be sent to the colonies (WSS296:1884).

Payment for care fees was guaranteed by the COS, which meant they collected the parental contributions. Guaranteeing to collect payment of these fees was a way for the COS to exercise control over applicants, giving an opportunity for them to monitor the family to ensure they were leading a satisfactory lifestyle. When parents defaulted on payments further inquiries were made to establish the reason why. If the COS were dissatisfied with the lifestyle of the applicant, or they did not follow their advice, they would terminate their support.

\section{Inconsistencies in approach to cases}

In some cases the COS response showed more sympathy with the parent, although the outcome for the child was not necessarily different.

Louisa (10) had two older brothers and their mother had recently died. Her father was described as a 'drunken, lazy, dirty low class fellow' who neglected his wife and children (WSS3273:1893). In other cases the father's drunken behaviour would have caused a COS referral to the Poor Law; monitoring applicants through careful case-records ensured that any indications that an applicant had a drinking-habit, or was lazy would prevent them from receiving relief (Koven, 2004). In this case, however, the child was accommodated as requested.

Sidney (8) was an illegitimate child, neglected and ill-treated by his step-father whose mother had deserted the family. Loch made the decision to provide support in this case, although in other similar cases he had been clear that the behaviour of the parents warranted a referral to the Poor Law (WSS324:1884).

In other cases the COS went to considerable efforts to help families. One example of proactive intervention was in the case of a family of four who lived 'in miserable rooms, almost destitute and filthy' with only one bed for the four of them. The seven year old girl was often seen begging. Their mother had died and their father had run out of work. COS advised they could not support the case unless it was 'part of a resolute attempt to 
deal with the whole family. This would include an effort to put the two girls into decent service and might involve preliminary training, and enforcement of John T's school attendance' (WSS1589:1888).

George (6) and Joseph (4) were referred when their mother was in hospital, their father was 'heavily in debt' but had just got a job. The COS considered that in order to 'give the man a chance of getting free from debt the children might be kept for a month free of charge' (WSS169/170:1883)

\section{Conclusion - historical parallels}

It is evident from these brief accounts that there were two distinct issues which could be contested between the COS visitors when acting as gatekeepers of the Waifs and Strays' accommodation for children, and poor parents. In some cases the question at issue was the provision or refusal of assistance. Families often saw the solution to their extreme poverty as including relief (temporary or permanent) from the burden of child care, while avoiding the Poor Law, and sought the charities' help in this respect. In these cases the COS might support the parents' wishes, might use their position of power to enforce changes in parental behaviour, or might refuse access entirely because the parents were seen as corrupt or insufficiently motivated. Other families, by contrast, wanted help and support to stay together, whilst the visitor might insist on them giving up one or more of their children. This means that what appears as a 'sympathetic' response in one case can seem harsh or controlling in another, although the outcome is the same (the removal of a child to a residential institution, 'boarding out' or emigration to the colonies).

Several things are striking about the attitudes to families, and in particular to children, revealed in these records. The focus is on parental behaviour, rather than on children's needs. Children are seen very clearly as their parents' responsibility rather than society's; there is little evidence here of the concept of 'children of the nation' which was to develop soon afterwards. In fact in 1893 the COS argued against the provision of school meals without inquiry, as it weakened the duty of the family (Mowat, 1961). There were powerful underlying concerns with moral issues, in particular illegitimacy, desertion, immorality, improvidence (the last even in relation to bereavement, where a parent was seen as having failed if they had not made provision in the event of their death). Getting 'something for nothing' was seen as demoralising. In particular, there was a very strong narrative of taking children away to 'relieve' the parent of a 'burden'. This period could perhaps be understood as a moment of transition, in Zelizer's (1985) terms, from children having economic value to having emotional value.

These attitudes should not be assumed to be universal for the time. There were competing value frames, including a view of children as especially deserving of compassion, exemplified of course by Dickens. Rudolf himself frequently rejected the harder-line recommendations of the COS visitors, showing a more compassionate 
approach. However, the COS officials and visitors were a powerful force, and many of them were on the boards of other charities or of Poor Law institutions. Inconsistencies and a lack of standardisation were apparent in the COS assessments; in some cases this can be explained by differences in responses between branches of the Society. The COS held generally firm views on illegitimacy and desertion, yet still adopted lenient attitudes in some cases. Conflict between the COS and the WSS was evident, particularly in relation to children being 'punished' for their parents' behaviour. Children's welfare was sometimes compromised in interagency disputes, when the COS withdrew help and attempted to encourage the WSS to do the same. In these cases Rudolf did not necessarily follow the COS; he tended to adopt a more child-centred approach, in contrast to the more adult-centred focus of the COS.

To some extent, the disdain shown by middle-class COS visitors towards the family life of poor people can be explained by the cultural context of a fear of the working class (Murdoch, 2006; Stedman Jones, 1971; Taylor, 2015). Yet, it is still surprising that the tragic circumstances described in some of these cases did not generate more sympathy from the visitors. Some of this can perhaps be explained by 'professional deformation' (Langerock, 1915): the COS approach was to focus on the causes of poverty within the individual, rather than the effects. Separating children from their families was seen as essential for parents to be self-supporting, even if they were 'deserving'. Furthermore, COS members, also associated with other welfare organisations, socialised together in a like-minded community which reinforced their views (Webb, 2007; Skinner, 2015). It is not known from the present research how many other WSS cases were influenced by the tone of COS interventions.

Almost thirty years ago, Fox Harding (1991) analysed contemporary child care law and policy in terms of four different perspectives: laissez-faire and patriarchy; state paternalism and child protection; defence of birth family and parents' rights; children's rights and child liberation. The COS approach could be understood as an example of the first, with small elements of the second. It is interesting to compare the approach of the COS visitors to contemporary attitudes to child welfare today. Blaming parents and punishing them by denying their children is still a feature of contemporary policies, and the distinction between 'deserving' and 'undeserving' poor has never really gone away (indeed, currently the 'deserving' category appears to be growing smaller). Although parents' rights and children's rights have both enjoyed a higher profile in recent times, both seem to be declining in influence at present. It is also interesting to compare what we see here of the dynamics of social work practice with contemporary analyses; for example, Holland (2000) has shown how clients (usually mothers) are seen as motivated to change if they agree with the social worker, and as resistant (and therefore 'risky' as parents) if they do not.

At a time when policy and practice in England is increasingly seeing removal of children, rather than family support, as the default response to problems of child care, when those family support services that remain are increasingly expected to be targeted 
at changing the behaviour of 'problem parents', and when 'getting parents into work' (by improving their skills or motivation) is once again a policy mantra, the work of the COS a century and a quarter ago seems disturbingly relevant.

\section{References}

Behlmer, G. (1982) Child Abuse and Moral Reform Reform in England 1870-1908, Stanford, Cal.: Stanford University Press.

Booth, C. (1889-91) Life and Labour of the people in London. London.

Bosanquet, C. (1874) A Handy-Book for Visitors of the Poor in London. London.

Bosanquet, H. (1914) Social Work in London 1869 to 1912. London.

Burnham, D. (2010) 'Selective Memory: A Note on Social Work Historiography', British Journal of Social Work, 1-17.

Carpenter, M. (1851) Reformatory Schools: For the Children of the Perishing and Dangerous Classes and for Juvenile Offenders. London.

Charity Organisation Society (1875) Fifth Annual Report.

Church of England Incorporated Society for Providing Homes for Waifs and Strays (1882-1920) Our Waifs and Strays (available at http://www.hiddenlives.org.uk/publications/waifs_and_strays, accessed 04/01/2017).

Church of England Incorporated Society for Providing Homes for Waifs and Strays (n.d.) Handbooks for Workers Part I, II and III (1904 version available at http://www.hiddenlives.org.uk/publications/handbook_for_workers, accessed 04/01/2017).

Cody, L. (2000) 'The Politics of Illegitimacy in an Age of Reform: Women, Reproduction, and Political Economy in England's New Poor Law of 1834', Journal of Women's History 11(4), 131-156.

Crompton, F. (1997) Workhouse Children: Infant and Child Paupers Under the Worcestershire Poor Law, 1780-1871, Stroud: Sutton Publishing.

Cunningham, H. (1991) The Children of the Poor. Representations of Childhood since the Seventeenth Century, Oxford: Blackwell.

Davenport, F. (1868) Children of the State; the training of juvenile paupers, London: Macmillan.

Davin, A. (1996) Growing Up Poor: Home, School and Street in London, 1870-1914, London: Rivers Oram Press.

Dingwall, R., Eekelaar, J. and Murray, T. (1984) 'Childhood as a Social Problem: A Survey of the History of Legal Regulation', Journal of Law \& Society, 11, 2, 207-232. 
Fox Harding, L. (1991) Perspectives in Child Care Policy. London: Longman.

Frost, G. (2013) 'Under the Guardian's Supervision: Illegitimacy, Family and the English Poor Law 1870-1930', Journal of Family History, 38, 2, 122-139.

Harris, J. (1994) Private Lives, Public Spirit: Britain 1870-1914, London.

Hendrick, H. (1994) Child Welfare: England 1872-1989. Routledge.

Hendrick, H. (1997) Children, Childhood and English Society 1880-1990, Cambridge University Press.

Heywood, J. (1978) Children in Care: the Development of the Service for the Deprived Child, London.

Himmelfarb, G. (1991) Poverty and Compassion: The Moral Imagination of the Late Victorians, New York.

Holland, S. (2000) 'The assessment relationship: interactions between social workers and parents in child protection assessments', British Journal of Social Work 30(2), 149-163.

Hollen Lees, L. (1998) The Solidarities of Strangers: the English Poor Laws and the People, 1700-1948, Cambridge.

Humphreys, R. (1995) Sin, Organised Charity and the Poor Law in Victorian England, London.

Hurren, E. (2007) Protesting about Pauperism, Poverty, Politics and Poor Relief in Late-Victorian England 1870-1900, Woodbridge.

Kidd, A. (1999) State, Society and the Poor in Nineteenth Century England, Oxford.

Langerock, H. (1915) 'Professionalism: A Study in Professional Deformation', American Journal of Sociology, 21, 1, 30-44.

Levine-Clark, M. (2010) 'From 'Relief' to 'Justice and Protection': The Maintenance of Deserted Wives, British Masculinity and Imperial Citizenship,1870-1920', Gender and History, 22, 2 , 302-321.

Lewis, J. (1991) Women and Social Action in Victorian and Edwardian England, Aldershot.

Lewis, J. (1995)The Voluntary Sector, the State and Social Work in Britain: the COS/Family Welfare Association since 1869, Aldershot.

Livesey, R. (2004) 'Reading for Character: Women Social Reformers and Narratives of the Urban Poor in Late Victorian and Edwardian London', Journal of Victorian Culture, 9, 1, 43-67.

Mackinnon, M. (1987) 'English Poor Law Policy and the Crusade against Outrelief', Journal of Economic History, 47,3, 603-625. 
Mayhew, H. (1851, 1968) London Labour and the London Poor. Dover.

Maxwell, J. (1997) 'Children and state intervention: developing a coherent historical perspective', in Rafferty, A-M., Robinson, J. and Elkan, R. (eds) Nursing History and the Politics of Welfare. London: Routledge.

Mearns, A. (1883) The Bitter Cry of Outcast London: An Inquiry into the Condition of the Abject Poor, London.

Mowat, C. L. (1961) The Charity Organisation Society 1869-1913: its ideas and work, London.

Murdoch, L. (2006) Imagined Orphans: Poor Families, Child Welfare, and Contested Citizenship in London. New Jersey and London.

Parker, R. (1990) Away from Home: A History of Child Care, Barnardo's, Ilford.

Philpot, T. (1994) Action for Children: The Story of Britain's Foremost Children's Charity, Oxford.

Pinchbeck, I. and Hewitt, M. (1983) Children in English Society, Vol II, London.

Prochaska, F. (1980) Women and Philanthropy in Nineteenth-Century England, Oxford.

Rooff, M. (1972) A Hundred Years of Family Welfare, A Study of the Family Welfare Association (Formerly Charity Organisation Society) 1869-1969, London.

Rose, M. (1986) The Relief of Poverty, 1834-1914, London-New York.

Rudolf, E. (1922) The First Forty Years: a chronicle of the Church of England Waifs and Strays' Society 1881-1920, Church of England Waifs and Strays' Society / SPCK.

Seebohm Rowntree, B. (1902 2 $2^{\text {nd }}$ Edn) Poverty, A Study of Town Life, London.

Skinner, A. (2015) 'Voice of the Visitors': An Exploration of the work of the Charity Organisation Society in Oxford, 1878-1889, Midland History, 40, 1.

Smith, M. (1965) Professional Education for social work in Britain. An Historical Account, London.

Soares, C. (2014) 'Neither Waif nor Stray: Home, Family and Belonging in the Victorian Children's Institution, 1881-1914', unpublished PhD, University of Manchester.

Stedman Jones, G. (1971) Outcast London, Oxford University Press.

Taylor, S. (2015) 'Poverty, Emigration and Family: Experiencing Childhood Poverty in Late Nineteenth-Century Manchester', Family \& Community History, 18,2, 91-103.

Thane, P. (1978) 'Women and the Poor Law in Victorian and Edwardian England, History Workshop, 6, 29-51. 
Thane, P. (2012) "The "Big Society" and the "Big State": creative tension or crowding out?' Twentieth Century British Hist., XXIII, 408-29.

Wagner, G. (1979) Barnardo, London.

Ward, H. (1990) 'The Charitable Relationship: Parents, Children and the Waifs and Strays Society', unpublished $\mathrm{PhD}$ thesis, Bristol.

Webb, S. (2007) 'The comfort of strangers: social work, modernity and late Victorian England-Part 1', European Journal of Social Work, 10, 1, 39-54.

Whelan, R. (2001) Helping the Poor. Friendly visiting, dole charities and dole queues, Civitas.

Woodroofe, K. (1962) From Charity to Social Work in England and the United States, London.

WSS Annual Reports, 1882-1899.

Young, A. and Ashton, E. (1956) British Social Work in the Nineteenth Century, London.

Zelizer, V. (1985) Pricing the Priceless Child: The Changing Social Value of Children, Basic Books Inc., New York.

\footnotetext{
${ }^{1}$ Goschen published the change to poor relief in the 1869 Poor Law Board Annual Report. Children were not usually direct recipients of outrelief unless they needed medical treatment. ${ }^{2}$ The full title was the Society for Organising Charitable Relief and Repressing Mendicity. (In 1946 it became the Family Welfare Association and more recently Family Action.) ${ }^{3}$ Loch was the National Secretary of the COS from 1875 to 1914 . According to his Times obituary notice: 'He made the COS; he was the COS' (Rooff 1972: 35). Bosanquet was a leading member of the COS, as well as its historian. Both were members of the Poor Law Commission of 1905. Lee was a member of the Executive Committee of the WSS and an Inspectress of WSS Boarded Out Children. She was also the Honorary Secretary of the St Marylebone District COS Committee, the first COS branch to be established, and a Poor Law Guardian.
} 